\title{
The Effect of Knowledge and Attitude toward Coronavirus Disease-19 Transmission Prevention Practice in South Sumatera Province, Indonesia
}

\author{
Ekowati Retnaningsih*, Nuryanto Nuryanto, Reni Oktarina, Oom Komalasari, Sri Maryani \\ Research and Development Board of South Sumatera Province, Indonesia
}

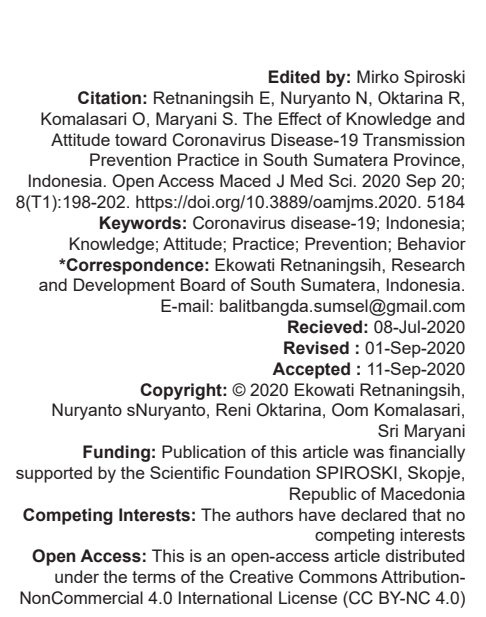

Introduction

Coronavirus (CoV) disease (COVID)-19 is a new infectious disease originating from Wuhan China caused by the CoV. The incubation period for COVID-19 is estimated to be between 2 and 14 days, depending on the age and immunity of the patient. This disease can spread to all age groups, especially in the elderly, and have a history of chronic illness. Common symptoms such as fever $\geq 38^{\circ} \mathrm{C}$, dry cough, and shortness of breath are increasingly dangerous but in some cases there are no symptoms. This disease can spread through small droplets from the nose or mouth patient when coughing or sneezing. The droplet then falls on the surrounding objects. If someone else touches an object that has been contaminated with the droplet, then that person touches the eyes, nose, or mouth (facial triangle), then that person can be infected with COVID-19. The diagnosis of COVID19 can be determined by examining a blood sample, throat swab test (sputum), or chest content [1], [2].

Globally and nationally, the number of COVID19 confirmation cases shows an exponential increase.
COVID-19 was first reported in Indonesia in early March 2019 in Jakarta, and by the end of April, it had spread to 34 provinces with 72 districts/cities with local transmission. Within 2 months, the number of cases increased to 10,118 cases with a CFR of $7.8 \%$. At the end of May, there was a two-fold increase to 26,473 cases spread across 129 local transmission districts/ cities [3], [4].

In South Sumatra, Indonesia, at the end of March 2020, the number of COVID-19 cases was reported as many as 5 cases, which within 2 months increased to 196 time to 982 confirmed cases at the end of May [4].

Transmission and spread of COVID-19 are very fast so prevention efforts need to be done. Referring to the WHO recommendations, the prevention of transmission from the community side is done by (1) implement Clean Healthy Practice especially washing hands using soap with running water, (2) stay at home, (3) social distancing/physical distancing, (4) use a mask when leaving the house, and (5) frequently clean the surface of objects that are frequently touched [5], [6], [7]. 
The South Sumatera Provincial Government since the beginning has carried out health promotion to increase public knowledge about COVID-19 so that the community is expected to be able to comply with COVID19 transmission prevention practice. However, the facts show a significant increase in the number of cases in South Sumatera. For this reason, a study is needed to determine the level of knowledge, attitudes, and practice of the public about COVID-19 and its influence on COVID-19 transmission prevention practice.

Approach of knowledge attitude practice model, its used to find out the relationship of knowledge, attitudes, and practice often used in studies of family planning and population has been a long time. Based on the knowledge, attitude, and practice model, it can also be known the effect of knowledge and attitudes toward practices directly and also the relationship of attitudes directly toward practice [8]. The approach knowledge, attitude, and practice model is an appropriate model for obtaining information about the relationship between knowledge, attitudes, and specific practices in specific populations [9].

Knowing the level of knowledge, attitudes, and practice as well as the possible risk factors can help to predict outcomes that will occur in health practice planning [10]. Public practice of the COVID-19 transmission prevention is very influential in decreasing cases that have now become a pandemic in 215 countries in the world [11], [12].

The purpose of this study was to determine the effect of knowledge, attitudes toward COVID-19 transmission prevention practice. By knowing this, appropriate interventions can be carried out to increase the positive practice of the community toward the prevention of COVID-19 transmission in Indonesia, particularly in South Sumatera Province.

\section{Methods}

\section{Research design}

This research was conducted with a quantitative method through a cross-sectional study approach. The population is all people who live in South Sumatra Province who use social media or WhatsApp and can access the Google form application. The research sample was taken from all respondents who filled out a questionnaire through Google form totaling 1187 people. The sampling technique was carried out through online responses because during the COVID-19 pandemic it was not possible to descend directly into spaciousness.

\section{Research procedure}

Data collection techniques are carried out by distributing questionnaires in a snowball through the
Google form application that is shared on social media Facebook and WhatsApp during the period from April 18, 2020 , to April 30, 2020. Preparation of the questionnaire based on COVID-19 Prevention and Control Guidelines issued by the Ministry of Health Republic of Indonesia [13].

\section{Research variable}

The data collected consist of dependent variables and independent variables. The dependent variable is COVID-19 transmission prevention practice. The independent variables are: (1) Respondent characteristics (location of residence, occupation, level of education, gender, and age); (2) knowledge of COVID-19; and (3) attitude toward COVID-19.

All numerical scale variables are grouped into categorical scales. Residential locations are categorized into two categories: District or city. Occupation is categorized into five namely: Civil servants/Army/ Police; health workers; private; housewife; and student/ student. Education level is categorized into high (high school graduation); middle (high school graduation); and low (not yet graduated from high school). Genders are categorized as male and female. Age is categorized into five groups 13-16 years, 17-25 years, 26-45 years, $46-65$ years, and $>65$ years.

While the variables of knowledge, attitudes, and practices use the median cutoff point by grouping: good (>median); and poor ( $\leq$ median). Respondent's knowledge of COVID-19 evaluated based on symptoms, transmission, and prevention which were assessed with 14 questions. The attitude of the respondents was assessed with eight questions. The practice of respondents was assessed with eight questions.

\section{Data analysis}

Data analysis was performed using parametric statistics, namely, univariate, bivariate, and multivariate. Univariate analysis to describe the frequency distribution and percentage of each variable: Characteristic respondens, knowledge, prevention practice and attitudes. Bivariate analysis to see the relationship of each independent variable with the dependent variable using Chi-squared test. Model candidate selection included in multivariate analysis is a variable that has a $p<0.25$ bivariate test results. Multivariate analysis was performed with a multiple logistic regression test using SPSS Version 26.

\section{Results}

In Table 1, it can be seen that majority of the subject lives in urban areas (58.9\%), civil servant/Army/ 


\section{Table 1: Characteristic of study subject}

\begin{tabular}{|c|c|}
\hline Characteristic & Frequency $(\%)$ \\
\hline \multicolumn{2}{|l|}{ Resident } \\
\hline City & $699(58.9)$ \\
\hline District & $488(41.1)$ \\
\hline \multicolumn{2}{|l|}{ Occupation } \\
\hline Civil servants/Army/Police & 425 (38.5) \\
\hline Health workers & $84(7.1)$ \\
\hline Private & $392(33.0)$ \\
\hline Housewife & $70(5.9)$ \\
\hline Student/college student & $216(18.2)$ \\
\hline \multicolumn{2}{|l|}{ Education } \\
\hline Low ( $\leq$ middle school) & $51(4.3)$ \\
\hline Intermediate (finish high school) & $181(15.2)$ \\
\hline High (> High school) & $955(80.5)$ \\
\hline \multicolumn{2}{|l|}{ Gender } \\
\hline Male & $472(39.8)$ \\
\hline Female & $715(60.2)$ \\
\hline \multicolumn{2}{|l|}{ Age groups (year) } \\
\hline $13-16$ & $60(7.2)$ \\
\hline $17-25$ & $246(20.7)$ \\
\hline $26-45$ & $659(55.5)$ \\
\hline $46-65$ & $217(18.3)$ \\
\hline$>65$ & $5(0.4)$ \\
\hline
\end{tabular}

Police occupations (38.5\%), high education levels from Diploma to doctoral graduates (80.5\%), gender women $(60.2 \%)$, and age of youth $(92.4 \%)$.

In Table 2, it can be seen that most subject have a good level of knowledge (55.3\%), good attitude (69.6\%), and good COVID-19 transmission prevention practice $(54.6 \%)$.

Table 2: The knowledge, attitudes, and COVID 19 transmission prevention practice of study subject

\begin{tabular}{ll}
\hline Variable & Frequency (\%) \\
\hline Knowledge & \\
Good & $656(55.3)$ \\
Poor & $531(44.7)$ \\
Attitude & \\
Good & $826(69.6)$ \\
Poor & $361(30.4)$ \\
Practice & \\
Good & $648(54.6)$ \\
Poor & $539(45.4)$ \\
\hline
\end{tabular}

In Table 3, it can also be seen that most subject get information from print media, electronic media, social media, friends, and family (60.0\%).

Table 3: Source information of study subject

\begin{tabular}{ll}
\hline Category & Frequency (\%) \\
\hline Print media, electronic media, social media, friend, and family & $712(60.0)$ \\
Electronic media, social media, friend, and family & $149(12.6)$ \\
Electronic media and social media & $70(5.9)$ \\
The other source & $256(21.6)$ \\
\hline
\end{tabular}

Based on Chi-square test, in Table 4, it can also be seen that the largest proportion of COVID-19 transmission prevention practices is in all categories for each independent variable, namely, (1) health workers (61.9\%), (2) higher education level (56.1\%); (3) female (57.8\%); (4) age group 46-65 years old $(63,6 \%) ;(5)$ good knowledge (62.8\%); and (6) good attitude (61.3\%). The results of the bivariate analysis showed that there were six independent variables, namely, occupation type, level of education, gender, age groups, level of knowledge about COVID-19, and attitudes toward COVID-19 affected COVID-19 transmission prevention practices $(p<0.05)$.

The final analysis results of the multiple logistic regression test showed that four variables are occupation (OR: 1.128; $p<0.01$ ), gender (OR: 1.309; $p<0.05$ ), level of knowledge (OR: 1.782; $p<0.01$ ),
Table 4: Chi-square test results

\begin{tabular}{|c|c|c|c|}
\hline \multirow[t]{2}{*}{ Variable } & \multicolumn{2}{|c|}{ Preventive practice (\%), $n=1187$} & \multirow[t]{2}{*}{$\mathrm{p}$-value } \\
\hline & Good & Poor & \\
\hline \multicolumn{4}{|l|}{ Resident } \\
\hline City & $392(56.1)$ & $307(43.9)$ & \multirow[t]{2}{*}{0.218} \\
\hline District & 256 (52.5) & $232(47.5)$ & \\
\hline \multicolumn{4}{|l|}{ Occupation } \\
\hline Civil servants/Army/Police & $260(61.2)$ & $165(38.8)$ & \multirow[t]{5}{*}{0.001} \\
\hline Health workers & $52(61.9)$ & $32(38.1)$ & \\
\hline Private & $201(51.3)$ & $191(48.7)$ & \\
\hline Housewife & $43(61.4)$ & $27(38.6)$ & \\
\hline Student/college student & $92(42.6)$ & $124(57.4)$ & \\
\hline \multicolumn{4}{|l|}{ Education } \\
\hline Low ( $\leq$ middle school) & $536(56.1)$ & 419 (43.9) & \multirow[t]{3}{*}{0.038} \\
\hline Intermediate (finish high school) & $88(48.6)$ & $93(51.4)$ & \\
\hline High (> High school) & $24(47.1)$ & 27 (52.9) & \\
\hline \multicolumn{4}{|l|}{ Gender } \\
\hline Male & $413(57.8)$ & $303(42.2)$ & \multirow[t]{2}{*}{0.007} \\
\hline Female & $235(49.8)$ & $237(50.2)$ & \\
\hline \multicolumn{4}{|l|}{ Age groups (year) } \\
\hline $13-16$ & $31(51.7)$ & $29(48.3)$ & \multirow[t]{5}{*}{0.002} \\
\hline $17-25$ & $112(45.5)$ & $134(54.5)$ & \\
\hline $26-45$ & $363(55.5)$ & 296 (44.9) & \\
\hline $46-65$ & $138(63.8)$ & $79(36.4)$ & \\
\hline$>65$ & $4(80)$ & $1(20)$ & \\
\hline \multicolumn{4}{|l|}{ Knowledge } \\
\hline Good & $412(62.8)$ & $244(37.2)$ & \multirow[t]{2}{*}{0.001} \\
\hline Less & 236 (44.4) & $295(55.6)$ & \\
\hline \multicolumn{4}{|l|}{ Level of attitude } \\
\hline Good & $506(61.3)$ & $320(38.7)$ & \multirow[t]{2}{*}{0.001} \\
\hline Poor & $142(39.3)$ & $219(60.7)$ & \\
\hline
\end{tabular}

and attitude (OR: 2.059; $p<0.01$ ) significantly affect the COVID-19 transmission prevention practice.

In Table 5, it can be seen that the variable with the strongest effect on COVID-19 transmission prevention practice is attitude (OR: 2.059; $p<0.01$ ). Probability of good practice of COVID-19 transmission prevention in subject with good attitudes toward COVID19 is 2059 times higher than subject poor attitude after being controlled by variables of occupation type, gender, and level of knowledge. Variable level of knowledge is also a relatively strong effect on COVID-19 transmission prevention practice (OR: 1.782; $p<0.01$ ). Probability of good practice of COVID-19 transmission prevention in subject with good COVID-19 knowledge is 1782 times higher than subject poor knowledge after being controlled by variables of occupation type, gender, and attitude.

Table 5: Final results of multiple logistic regression analysis

\begin{tabular}{llll}
\hline Variable & $\mathrm{p}$-value & OR & $95 \% \mathrm{Cl}$ OR \\
\hline Occupation & 0.004 & 1.128 & $1.038-1.226$ \\
Gender & 0.031 & 1.309 & $1.025-1.672$ \\
Knowledge & 0.001 & 1.782 & $1.398-2.271$ \\
Attitude & 0.001 & 2.059 & $1.548-2.676$ \\
\hline
\end{tabular}

\section{Discussion}

The results of this study indicate that the majority of subjects (54.6\%) implement good COVID-19 transmission prevention practice. Wango et al. stated that all people, both health workers, and non-health workers must follow the same protection standards, namely, wearing masks, regularly washing hands, and using hand sanitizers. Some standards such as wearing a mask are felt to cause social discomfort, which can 
cause stress but at the same time if they did not wear masks, risk of COVID-19 infection is high [14].

This study found that the variables of knowledge, attitude, type of work, and gender affect COVID-19 transmission prevention practice $(p<0.05)$. Variables that have strong effect are attitude (OR: 2.059; $p<0.01)$ and knowledge (OR: 1.782; $p \leq 0.01$ ). In line with the results of Zhong et al. study which shows that gender, occupation, and knowledge are significantly related $(p<0.05)$ with COVID-19 prevention practice (social distancing). Gender and knowledge are significantly related $(p<0.05)$ with COVID-19 prevention practice (mask use) [15].

To prevent increase COVID-19 positive cases, transmission in the community must be carried out. Prevention of transmission will be achieved if each individual implement good COVID-19 transmission prevention practice. For this reason, efforts should be made to increase knowledge and improve community attitudes continuously through increasing the number and quality of health promotion to the community regarding COVID-19 transmission prevention. In line with the results of Shivalenge's study which states that there is a strong and significant relationship between knowledge and practice of COVID-19 transmission prevention [16]. This is in line with the results of Azlan et al. study, which shows that knowledge is significantly $(p<0.05)$ with COVID19 transmission prevention practice (social distancing and mask use) [17]. Different results were found from the results of Saqlain et al. study, which showed that knowledge was not significantly affect to COVID-19 related practice in the health workforce group [18].

Health knowledge can be obtained by the public through the media and advances in information technology such as the internet, with adequate supervision from parents [19]. Clear and precise information and instructions on the prevention practice of severe acute respiratory syndrome-CoV-2 transmission that must be practiced by everyone to reduce exposure to the virus is a very important element in reducing the spread of COVID19. One of the media used by millions of people to get information about COVID-19 is social media YouTube, with users of more than 2 billion people [20].

Health promotion can be done through print media, electronic media, social media, peer group approaches, and instructions or appeals from the Regional Head, both the Governor and the Regent/ Mayor through some communication media. This study found that most subjects obtained information from print media, electronic media, social media, friends, and family. The results of this study are similar to the results of Afzal Basha's study which shows that subject knows things related to COVID-19 through social media (64\%), electronic/TV media (27\%), and print media (9\%) [21].

The study also found that a positive attitude toward COVID-19 transmission prevention significantly affect the good COVID-19 transmission prevention practice after being controlled by other variables. The results of Paul et al. study in Bangladesh showed that a positive attitude toward COVID-19 was influenced by a good knowledge of COVID-19. Respondents with better knowledge have a positive attitude toward social distancing (OR: 2.056; $p<0.01$ ). This shows the important role of the government to educate the public, bearing in mind that good knowledge will form positive attitude toward COVID-19 transmission prevention [9].

This study shows that women have a greater chance (OR: 1.309; $p$-value) to behave better in preventing transmission of COVID 19 than men. These findings are in line with the results of Azlan et al. study, which shows that gender is significantly related $(p<0.05)$ with COVID-19 transmission prevention practice (use of hand sanitizers and mask use) [17].

The results of this study also showed that occupational groups also affect COVID-19 transmission prevention practice. The proportion of private worker groups who implement good COVID-19 transmission prevention practice $(51.3 \%)$ was smaller than the civil servants/Army/Police (61.2\%). Many of these groups do not do social distancing and find it difficult to do physical distancing because they cannot work from home. They stay out of the house to get income for fear of being laid off and salary cuts. This condition in line with the findings of Shubha study who stated that the impact of the COVID-19 pandemic in the labor sector caused nearly 25 million workers to lose their jobs. Job losses and salary cuts are the most likely to occur in several sectors; airlines, hotels, commerce, malls, restaurants, and more. The company did not reach the income target and was forced to reduce the number of employees [22].

According to Pakpour and Griffiths, the effects of the COVID-19 pandemic were causing Millions of people in the world lockdown at home and many do not allow work to earn money because they cannot carry out their duties from home [23]. The same thing was conveyed by Malagi et al. again that many residents will lose their jobs, especially in the fields of retail, hospitality, travel, and construction sector. The government is expected to provide incentives for these companies to keep their workers until the CoV problem ends [24].

\section{Conclusion}

This study confirms that factors affecting COVID-19 transmission prevention practice are occupation type, gender, level of knowledge, and attitude. The dominant factor affecting COVID 19 transmission prevention practice is attitude (OR: 2.059; $p<0.01$ ) and knowledge (OR: 1.782; $p<0.01$ ). Hence, it is necessary to increase community knowledge about COVID-19 better to increase people's attitudes toward COVID 19 transmission prevention so they implement COVID-19 transmission prevention practice. 


\section{Acknowledgment}

Thank you to H. Herman Deru, Governor of South Sumatera, Research and Development Board of South Sumatera Province, South Sumatera Researchers Association (Himpenindo of South Sumatera) and all stakeholders who have helped to share questionnaires on social media and WhatsApp, and all respondents who have contributed in this research.

\section{References}

1. Zhu N, Zhang D, Wang W, Li X, Yang Bo, Song J, et al. A novel coronavirus from patients with pneumonia in China, 2019. N Engl J Med. 2020;382(8):727-33. https://doi.org/10.1056/ nejmoa2001017

PMid:31978945

2. World Health Organization. Report of the WHO-China Joint Mission on Coronavirus Disease 2019 (COVID-19). Geneva: World Health Organization; 2020. Available from: https://www.who. int/docs/default-source/coronaviruse/who-china-joint- mission-oncovid-19-final-report.pdf. [Last accessed on 2020 Jun 17].

3. World Health Organization. Coronavirus Disease 2019 (COVID19) Situation Report 71. Geneva: World Health Organization; 2020. Available from: https://www.who.int/docs/default-source/ coronaviruse/situation-reports/20200331-sitrep-71-covid-19. pdf?sfvrsn=4360e92b_8. [Last accessed on 2020 Jun 15]

4. Kemkes. Situasi Terkini Perkembangan Novel Coronavirus (COVID-19); 2020. Available from: https://www.covid19.kemkes. go.id/situasi-infeksi-emerging/info-corona-virus/situasi-terkiniperkembangan-coronavirus-disease-covid-19-31-mei-2020/\# XwPkXOcxXIU. [Last accessed on 2020 Jul 01].

5. World Health Organization. Coronavirus Disease 2019 (COVID19) Situation Reports 72. Geneva: World Health Organization; 2020. Available from: https://www.who.int/docs/default-source/ coronaviruse/situation-reports/20200401-sitrep-72- covid-19. pdf?sfvrsn=3dd8971b_2. [Last accessed on 2020 Jun 17].

6. Bender L. Key Messages and Actions for COVID-19 Prevention and Control in Schools. New York: UNICEF; 2020. Available from: https://www.who.int/docs/default-source/coronaviruse/keymessages-and-actions-for-covid-19-prevention-and-control-inschools-march-2020.pdf?sfvrsn=baf81d52_4. [Last accessed on 2020 Jun 16]

7. World Health Organization. Coronavirus Disease (COVID-19) Advice for the Public. Geneva: World Health Organization; 2020. Available from: https://www.who.int/emergencies/diseases/ novel-coronavirus-2019/advice-for-public. [Last accessed on 2020 Jun 17]

8. You S, Han W. Approaching knowledge, attitudes, and practices model for elderly with dementia who are suspected to have hearing impairment in Korea. J Audiol Otol. 2020;24(1):40-7. https://doi.org/10.7874/jao.2019.00094 PMid:31319639

9. Paul A, Sikdar D, Hossain MM, Amin MR, Deeba F, Mahanta J, etal. Knowledge Attitude and Practice Towards Novel Corona Virus among Bangladeshi People Implications for Mitigation Measures. Medrxiv; 2020. https://doi.org/10.1101/2020.05.05.20091181
10. Zhang M, Zhou M, Tang F, Wang $\mathrm{Y}$, Nie H, Zhang L, et al Knowledge, attitude, and practice regarding COVID-19 among healthcare workers in Henan, China. J Hosp Infect. 2020;105(2):183-7. https://doi.org/10.1016/j.jhin.2020.04.012 PMid:32278701

11. World Health Organization. Coronavirus Disease 2019 (COVID19) Situation Report 154. Geneva: World Health Organization; 2020. Available from: https://www.who.int/docs/default-source/ coronaviruse/situation-reports/20200622-covid-19-sitrep-154. pdf?sfvrsn=d0249d8d_2. [Last accessed on 2020 Jun 15].

12. Kemkes. Situasi Terkini Perkembangan Novel Coronavirus (COVID-19). Available from: https://www.covid19.kemkes. go.id/situasi-infeksi-emerging/info-corona-virus/situasi-terkiniperkembangan-coronavirus-disease-covid-19-21-juni-2020/\#. XwPjEOcxXIU. [ Last accessed on 2020 Jul 01].

13. Kementrian Kesehatan. Pedoman Pencegahan dan Pengendalian Coronavirus Disease (COVID-19); 2020. Available from: https://www.kemkes.go.id/article/view/20031700001/ Dokumen-Resmi-dan-Protokol-Penanganan-COVID-19.html. [Last accessed on 2020 Jun 17].

14. Wango G, Wairire GG, Kimamo C. Anxiety and Emotions of COVID19: The Emotional Underpinnings of Dealing with the Corona Virus Disease; 2020. Available from: https://www.researchgate. net/publication/341426454 anxiety and_emotions of covid19_the_emotional_underpinnings_of_dealing_with_the_corona_ virus_disease. [Last accessed on 2020 Jun 17].

15. Zhong BL, Luo W, Zhang QQ, Liu XG, Li WT, Li Y, et al. Knowledge, attitudes, and practices towards COVID-19 among chinese residents during the rapid rise period of the COVID-19 outbreak: A quick online cross-sectional survey. Int J Biol Sci. 2020;16(10):1745-52. https://doi.org/10.7150/ijbs.45221

16. Kamate SK, Sharma S, Thakar S, Srivastava D, Sengupta K, Hadi AJ, et al. Assessing knowledge, attitudes and practices of dental practitioners regarding the covid-19 pandemic: A multinational study. Dent Med Probl. 2020;57(1):11-7. https:// doi.org/10.17219/dmp/119743

17. Azlan AA, Hamzah MR, Sern TJ, Ayub SH, Mohamad E. Public knowledge, attitudes and practices towards COVID-19: A crosssectional study in Malaysia. PLoS One. 2020;15(5):1-15. https:// doi.org/10.37473/dac/10.1101/2020.04.29.20085563.

18. Saqlain M, Munir MM, Rehman SU, Gulzar A, Naz S, Ahmed Z, et al. Knowledge, attitude, practice and perceived barriers among healthcare workers regarding COVID-19: A crosssectional survey from Pakistan. J Hosp Infect. 2020;105(3):41923. https://doi.org/10.1016/j.jhin.2020.05.007

19. Syamsiah S, Lipoeto NI, Nurdin AE, Bachtiar A. Health behavior prediction model based on health literacy among mothers with obesity children. Open Access Maced J Med Sci. 2020;8:87-90. https://doi.org/10.3889/oamjms.2020.4178

20. Basch CH, Hillyer GC, Meleo-Erwin ZC, Jaime C, Mohlman J, Basch CE. Education the public about reducing exposure to SARS-CoV-2: Preventive behaviors conveyed on youtube to mitigate transmission of COVID-19. JMIR Public Health Surveill. 2020;6(2):e19601.

21. Basha A, Parthasarathi SK, Aktharsha US. A study on impact of COVID-19 pandemic on consumer buying behavior in Bangalore City. J Emerg Technol Innov Res. 2020;7(4):1396-404.

22. Shubha.CS. Effect of COVID-19 and historical background a study. J Emerg Technol Innov Res. 2020;7(4):2104-14

23. Pakpour AH, Griffiths MD. The fear of COVID-19 and its role in preventive behaviors. J Concurr Disord. 2020;2020:39561.

24. Malagi SS. Impact of COVID-19 on the Indian economy-A study. J Emerg Technol Innov Res. 2020;7(4):1629-37. 